\title{
Effect of seed inoculation with Azospirillum brasilense and nitrogen fertilization rates on maize plant yield and silage quality
}

\author{
Fernando Reimann Skonieski ${ }^{*}$, Julio Viégas ${ }^{2}$, Thomas Newton Martin ${ }^{3}$, José Laerte Nörnberg ${ }^{4}$, \\ Gilmar Roberto Meinerz ${ }^{5}$, Tiago João Tonin ${ }^{6}$, Priscila Bernhard ${ }^{6}$, Marcela Tostes Frata ${ }^{1}$
}

\author{
1 Universidade Tecnológica Federal do Paraná, Dois Vizinhos, PR, Brazil. \\ 2 Universidade Federal de Santa Maria, Departamento de Zootecnia, Santa Maria, RS, Brazil. \\ ${ }^{3}$ Universidade Federal de Santa Maria, Departamento de Fitotecnia, Santa Maria, RS, Brazil. \\ ${ }^{4}$ Universidade Federal de Santa Maria, Departamento de Tecnologia e Ciência de Alimentos, Santa Maria, RS, Brazil. \\ ${ }^{5}$ Universidade Federal da Fronteira Sul, Cerro Largo, RS, Brazil. \\ ${ }^{6}$ Universidade Federal de Santa Maria, Programa de Pós-graduação em Zootecnia, Santa Maria, RS, Brazil.
}

\begin{abstract}
The objective of this study was to determine the effect of Azospirillum brasilense inoculation and different nitrogen $(\mathrm{N})$ rates applied as topdressing on the productivity of a maize crop and the nutritional value of maize silage. Two experiments were conducted in the 2012/2013 and 2013/2014 harvests. Treatments were distributed in a randomized block design in a factorial arrangement, which consisted of two maize hybrids (AS 1572 and Defender) coupled with nitrogen rates $\left(0,60,120,240\right.$, and $\left.480 \mathrm{~kg} \mathrm{ha}^{-1}\right)$, inoculated or uninoculated with $A$. brasilense. Inoculated seeds were treated with the A. brasilense strains Ab-V5 and Ab-V6. Inoculation with A. brasilense showed interaction with the hybrids, agricultural years, and nitrogen rates for the maize plant yield. In the 2012/2013 agricultural year, inoculation increased the AS 1572 hybrid silage yield by $6.16 \%$ and, in the $2013 / 2014$ harvest, A. brasilense inoculation produced an increase of $16.15 \%$ for the Defender hybrid. Nitrogen fertilization applied at 0,60 , and $120 \mathrm{~kg} \mathrm{ha}^{-1} \mathrm{~N}$ benefited the plants inoculated with $A$. brasilense The statistical equations revealed that $\mathrm{N}$ rates between 0 and $184 \mathrm{~kg} \mathrm{ha}^{-1}$ in $A$. brasilense inoculated plants raised the plant productivity for silage when compared with the control plants. Regarding the nutritional value of the silage, inoculation with A. brasilense increased the ether extract levels and total digestible nutrients and reduced the amount of acid detergent fiber. For all this, positive results with inoculation for silage yield are dependent on nitrogen fertilization rate. Inoculation with $A$. brasilense can promote changes in the maize silage quality, but with obtained results it is not possible to definitely conclude upon nutritive value of maize silage.
\end{abstract}

Key Words: diazotrophic bacteria, morphological composition, nitrogen fertilization, nutritional value, silage yield

\section{Introduction}

The use of diazotrophic bacteria to increase crop yields has been described in the literature (Bashan and Bashan, 2010; Hungria et al., 2010; Moutia et al., 2010). The increase of vegetative productivity of inoculated plants has been attributed to several mechanisms. However, biological nitrogen fixation (BNF) (Morais et al., 2012) and the synthesis of phytohormones (Cassan et al., 2009) seem to be the most likely mechanisms. There are some advantages,

Received: February 10, 2017

Accepted: June 10, 2017

*Corresponding author: fskonieski@yahoo.com.br

http://dx.doi.org/10.1590/S1806-92902017000900003

How to cite: Skonieski, F. R.; Viégas, J.; Martin, T. N.; Nörnberg, J. L.; Meinerz, G. R.; Tonin, T. J.; Bernhard, P. and Frata, M. T. 2017. Effect of seed inoculation with Azospirillum brasilense and nitrogen fertilization rates on maize plant yield and silage quality. Revista Brasileira de Zootecnia 46(9):722-730.

Copyright (c) 2017 Sociedade Brasileira de Zootecnia. This is an Open Access article distributed under the terms of the Creative Commons Attribution License (http://creativecommons.org/licenses/by/4.0/), which permits unrestricted use, distribution, and reproduction in any medium, provided the original work is properly cited. such as an efficient use of nutrients, increased uptake, and increased concentration of nitrogen $(\mathrm{N})$ and other mineral elements in the plants (Dobbelaere et al., 2002; Moutia et al., 2010), including maize (Hungria et al., 2010), when seeds are inoculated with Azospirillum spp., either by BNF or an increase in the root surface area.

Nitrogen is the most required nutrient during grass development (Fontoura and Bayer, 2009). Because of the low concentration of available nitrogen in the tropical and subtropical soils, applied nitrogen fertilization significantly changes the morphology of the aerial parts of the plants. Nitrogen also promotes stem elongation, leaf emission and expansion, more green leaves, and increases the leaf area and the photosynthetic capacity, among other effects in grasses (Patês et al., 2007; Machado et al., 2013, Castagnara, et al., 2014), including maize (Sangoi et al., 2011; Imran, et al., 2015). Thus, inoculation with Azospirillum brasilense with or without nitrogen fertilization may provide some benefits to a crop, although such interactions are not completely understood. 
Increased nutrient assimilation, including that of nitrogen, may determine the development of the morphological and reproductive structures as well as the proportion of the stem, leaves, and cobs/grains. Furthermore, nutrient assimilation may also promote changes in the histology of plant tissues, such as the deposition of the mesophyll cells, the parenchyma, the sclerenchyma, among other tissues (Wilson, 1993), which have different cell walls and concentrations of cell contents. Both morphological and histological anatomical changes affect the crude protein content, the structural carbohydrates, the soluble carbohydrates, energy, and other nutrients that are essential to animal nutrition. In this context, the objective of this study was to determine plant productivity and the nutritional value of hybrid maize silage inoculated or uninoculated with Azospirillum brasilense strains Ab-V5 and $\mathrm{Ab}-\mathrm{V} 6$ treated with $\mathrm{N}$ rates applied as topdressing.

\section{Material and Methods}

The experiment was carried out in a field owned in Erechim, RS, during the 2012/2013 and 2013/2014 harvests. The field is located in the physiographic region of Alto Uruguai, RS, Brazil, at an altitude of $760 \mathrm{~m}, 27^{\circ} 65$ south latitude, and $52^{\circ} 30$ west longitude.

The climate is classified as Cfa (warm climate, fully humid with a hot summer) (Peel et al., 2007), with mean annual rainfall of $1869 \mathrm{~mm}$, annual potential evapotranspiration of $844.9 \mathrm{~mm}$, mean annual temperature of $18.2^{\circ} \mathrm{C}$, with minimum mean of $13.5^{\circ} \mathrm{C}$ in July, maximum mean of $22.6{ }^{\circ} \mathrm{C}$ in January, and relative humidity of 78.6\% (CEMETRS, 2012) (Figure 1).

During the winter, the areas were cultivated in no-tillage system with black oats (Avena strigosa L.), a common cultivar for the formation of auxiliary straw for the tillage system to prevent nutrient loss. When the crops were in

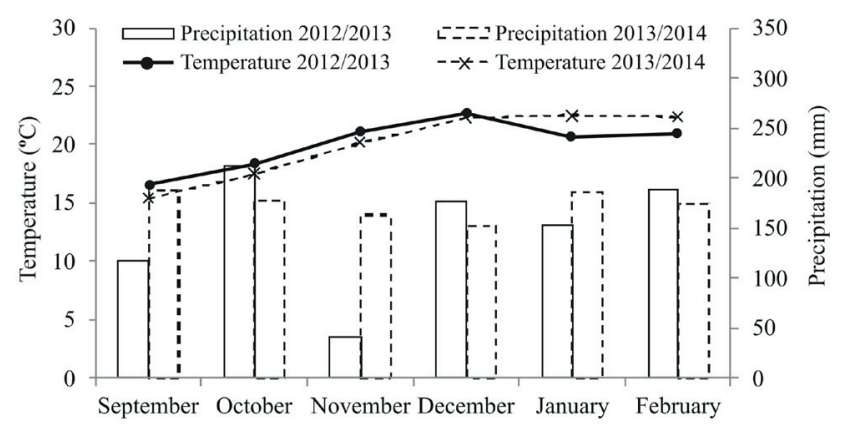

Figure 1 - Accumulated rainfall and mean air temperature during the experiment in Erechim, RS, in 2012/2013 and 2013/2014. full bloom, the area was desiccated with the herbicide glyphosate.

The soil of the region is characterized as a Latossolo Vermelho Aluminoférrico Húmico by the Brazilian Soil Classification (EMBRAPA, 2013; Streck et al., 2008), and as a Rhodic Ferralsols (Alumic) according to the FAO World Reference Base for Soil Resources (WRB, 2014).

Soil samples from the $0-20 \mathrm{~cm}$ layer were taken for the analysis of the chemical properties and then soil fertilization recommendations were obtained. The following soil chemical characteristics were observed: clay $=60.0 \%$; $\mathrm{pH}$ in water $=5.5$; cation exchange capacity $=13.6 \mathrm{cmol}_{\mathrm{c}} \mathrm{dm}^{-3}$; $\mathrm{Al}=0.2 \mathrm{cmol}_{\mathrm{c}} \mathrm{dm}^{-3} ; \mathrm{Ca}=6.4 \mathrm{cmol}_{\mathrm{c}} \mathrm{dm}^{-3} ; \mathrm{Mg}=2.6 \mathrm{cmol}_{\mathrm{c}} \mathrm{dm}^{-3}$; $\mathrm{P}=9.0 \mathrm{mg} \mathrm{dm}^{-3} ; \mathrm{K}=287 \mathrm{mg} \mathrm{dm}^{-3}$; organic matter $=3.3 \%$; and base saturation $=70.7 \%$.

Phosphorus and potassium fertilizations were performed according to the indications of Comissão de Fertilidade do Solo - RS/SC (2004). Phosphorus and potassium fertilization were performed by applying an equivalent level of $45.85 \mathrm{~kg} \mathrm{ha}^{-1}$ of $\mathrm{P}_{5}$ and $41.52 \mathrm{~kg} \mathrm{ha}^{-1}$ of $\mathrm{K}$ as triple super phosphate and potassium chloride, respectively.

A nitrogen fertilizer was applied as urea with $45 \% \mathrm{~N}$ at an equivalent level of $30 \mathrm{~kg} \mathrm{~N} \mathrm{ha}^{-1}$ in the cultivation row at sowing. The remaining fertilizer was applied equally in topdressing during the phenological stages of four and eight developed leaves. The urea was distributed at different levels of $\mathrm{N}$ that comprised the following treatments: 0,60 , 120,240 , and $480 \mathrm{~kg} \mathrm{ha}^{-1}$ of $\mathrm{N}$. In the treatments without nitrogen, nitrogen fertilization was not carried out, either during sowing or as topdressing.

The maize crop was established on 09/16/2012 and $09 / 26 / 2013$ using a no-tillage system, with a spacing of $0.66 \mathrm{~m}$ between rows and $0.25 \mathrm{~m}$ between plants in a line, in plots of nine rows, with dimensions of $5.0 \times 5.28 \mathrm{~m}$. Two maize genotypes were sown, AS $1572^{\circledR}$ and Defender ${ }^{\circledR}$, both simple hybrids with early maturity and genetically modified for resistance to the fall armyworm, the sugarcane borer (Diatraea saccharalis), and the maize earworm (Helicoverpa zea). The seeds were treated with fungicide and insecticide by the supplier agroindustry.

Weed control was applied in the first phase of the developed leaf as a Triazine herbicide that had atrazine and simazine as the active ingredients. In both years, a systemic selective herbicide with tembotrione as active ingredient was applied between the crop rows during the six-leaf phase.

Prior to sowing, the maize seeds were inoculated with Azospirillum brasilense strains Ab-V5 and Ab-V6 at a concentration of $2.0 \times 10^{8} \mathrm{cfu} \mathrm{mL}^{-1}$ and $6.6 \times 10^{6} \mathrm{cfu} \mathrm{seed}^{-1}$ using $200 \mathrm{~mL} \mathrm{ha}^{-1}$ of the AzoTotal $^{\circledR}$ inoculant (Total 
Biotecnologia) with a measuring cup. To avoid possible contamination of the seeds, the uninoculated seeds were sown before the inoculated seeds.

The experiment design was designed as randomized blocks, with 20 treatments and three replicates. The area declivity was standardized to arrange the blocks. The treatments were distributed in a factorial arrangement consisting of two hybrid maize silage (AS 1572 and Defender) with nitrogen rates $\left(0,60,120,240\right.$, and $\left.480 \mathrm{~kg} \mathrm{ha}^{-1}\right)$, uninoculated or inoculated with Azospirillum brasilense. Harvest was carried out when the majority of grains were between the dough and dent stages, at $20 \mathrm{~cm}$ above the ground, from three centrals rows of the experimental plots. The counting the plants per plot was performed to obtain the amount of plants per hectare. Harvested plants were identified and weighed to obtain the yield per plant (green plant weight) and estimate the yield per hectare. Silage was prepared at 121 and 119 days after plant emergence, with an accumulated thermal sum of 1,241.4 and 1,291.6 day degrees, in the 2012/2013 and 2013/2014 harvests, respectively.

Three representative plants per plot were randomly collected for the evaluation of plant morphological composition. The stems, leaves, cobs, straws, senescent material, and tassels were manually separated. The morphological component samples and three whole plants were ground, packed in paper bags, and air-dried in a forced ventilation greenhouse at $55{ }^{\circ} \mathrm{C}$ for approximately $72 \mathrm{~h}$ to obtain an estimate of the dry matter (DM) and determine the plant yield for silage and the morphological components in $\mathrm{kg} \mathrm{DM} \mathrm{ha}^{-1}$.

The remaining forage in the three central rows of the plots was immediately ground to an average particle size of $2 \mathrm{~cm}$ and ensiled within miniature laboratory silos. The silos contained $10 \mathrm{~kg}$ of maize green mass. For anaerobic fermentation, this material was manually compacted with packing density of $550 \mathrm{~kg}$ of green matter $\mathrm{m}^{-3}$. The silos were made with double polypropylene plastic bags of 0.6 micron-thick each. Prior to the closing of the silos, the remaining air was removed by means of air compressor. The silos were involved by black plastic film to prevent solar radiation exposure and stored in a protected place from moisture, heat, and direct sunlight. At the bottom of each silo, $2 \mathrm{~kg}$ of washed and dried sand was added to drain effluents. The ensiled material was separated from the sand by cloth filter.

The silos were opened after approximately 70 days of ensilage. The chemical analyses were performed in Santa Maria, RS. A silage sample from each silo was pressed by a Carver laboratory press for silage effluent extraction. The silage effluent was used for the $\mathrm{pH}$ evaluation with a digital potentiometer (Wilson and Wilkins, 1972). The ammoniacal nitrogen was determined in relation to the total nitrogen $\left(\mathrm{NH}_{3}-\mathrm{N} / \mathrm{TN}\right)$ in the effluent by distillation with magnesium oxide (AOAC, 1995).

Another sample of approximately $500 \mathrm{~g}$ was pre-dried in a forced-air oven at $55^{\circ} \mathrm{C}$ for $72 \mathrm{~h}$ and ground in a Wiley mill with 1-mm sieves for dry matter (DM) estimate. The total dry matter was evaluated with samples in a forced-air oven at $105{ }^{\circ} \mathrm{C}$ for $16 \mathrm{~h}$, while the crude protein (CP) was determined by micro Kjeldahl method (AOAC, 1995). The ether extract (EE) was analyzed with a Soxhlet extractor with light petroleum and the mineral matter (MM) was obtained by incineration in a muffle furnace at $550{ }^{\circ} \mathrm{C}$ for $4 \mathrm{~h}$ (AOAC, 1995). The neutral detergent fiber (NDF) was obtained according to the method of Van Soest et al. (1991), with a subsequent correction for ash and protein (NDFap), and the acid detergent fiber (ADF) and acid detergent lignin was obtained according to the method of Goering and Van Soest (1970).

The non-fiber carbohydrates (NFC) and the total digestible nutrients (TDN) were estimated according to the NRC (2001) by the following equations: NFC (\%) = $100-(\mathrm{CP}+\mathrm{MM}+\mathrm{NDFap}+\mathrm{EE})$ and TDN1x $=$ NFCtd $+\mathrm{CPtd}+(\mathrm{EE}-1) \times 2.25+\mathrm{NDFtd}-7$, in which TDN1x (\%) refers to the total digestible nutrients consumed at one time for maintenance; NFCtd indicates the truly digestible non-fiber carbohydrates; CPtd indicates the truly digestible crude protein; NDFtd indicates the truly digestible neutral detergent fiber; and 7 is a constant that represents loss of metabolites in the feces. The neutral detergent insoluble nitrogen (NDIN) and acid detergent insoluble nitrogen were estimated according to Licitra et al. (1996).

The data were tested for normality and an analysis of variance and a subsequent multiple-comparison of the means by the mixed procedure (PROC MIXED) were performed to study the factors in isolation and their interactions by using the SAS statistical package (Statistical Analysis System, version 9.3). Significant interactions were merged according to the treatments and then subjected to the means and compared by GLM procedure (PROC GENERALIZED LINEAR MODEL). For the features evaluated according to the maize hybrid and inoculation with Azospirillum brasilense, the comparative means were calculated with the aid of the Tukey test. However, the variables evaluated for the different levels of $\mathrm{N}$ were estimated by regression equations at $5 \%$ significance level. The statistical models were chosen according to the significance of the regression and determination coefficients $\left(\mathrm{R}^{2}\right)$ and the biological phenomenon studied. The Pearson correlation test was 
performed for all variables. The agricultural year factor was included as a random variable in the model because of the lack of an experimental control and the inability to repeat the environmental conditions of the experiment.

\section{Results}

The inoculation response was different for different agricultural years. The DM yield of plants for silage was increased in the 2013/2014, but the same effect was not observed in the 2012/2013 agricultural year (Table 1). The inoculation increased the DM yield of the plants by $4.35 \%$ in the 2013/2014 agricultural year. These results demonstrated the variability in the maize response to the inoculation with $A$. brasilense due to the different harvests and environment interactions.

Table 1 - Interaction between inoculation with Azospirillum brasilense and agricultural years on silage plant yield $\left(\mathrm{kg} \mathrm{DM} \mathrm{ha}{ }^{-1}\right)$

\begin{tabular}{lccc}
\hline Silage plant yield & $2012 / 2013$ & $2013 / 2014$ & Mean \\
\hline Azospirillum brasilense & $14,107 \mathrm{~b}$ & $14,722 \mathrm{a}$ & 14,414 \\
Control & $14,561 \mathrm{a}$ & $14,051 \mathrm{~b}$ & 14,306 \\
Mean & 14,334 & 14,387 & \\
\hline
\end{tabular}

DM - dry matter.

Means followed by different letters in the column differ according to the $\mathrm{F}$ test $(\mathrm{P}<0.05)$.
An interaction between the inoculation with $A$. brasilense and maize hybrids was observed for the weight of the green plant, DM yield, ear, leaf, and tassel (Table 2). The Defender hybrid inoculated with $A$. brasilense showed greater weight of the green plant and DM yield. In this case, the inoculation produced an increase of $574 \mathrm{~kg} \mathrm{ha}^{-1}$ or $3.93 \%$ over the DM yield of plants for silage (Table 3 ). Defender hybrid inoculated with $A$. brasilense showed a higher ear and lower leaf percentage when compared with uninoculated hybrid (Table 3).

A positive effect for DM yield of the inoculation with A. brasilense associated with the Defender hybrid was indicated by the mean of the two agricultural years. However, an analysis of the interaction between inoculation and hybrid within each agricultural year indicated an increase of $16.15 \%$ for DM yield with the Defender hybrid inoculated in the 2013/2014 agricutural year. This phenomenon was not found in the previous agricultural year for this hybrid, with no significant results. Inoculation with A. brasilense produced an increase of $6.16 \%$ in the DM yield of the AS 1572 hybrid inoculated with $A$. brasilense for the 2012/2013 agricultural year. In 2013/2014, there was inversion of the results for this hybrid, with superiority for the treatment without $A$. brasilense.

Increase of $\mathrm{N}$ rates changed the response to inoculation with $A$. brasilense. Nitrogen rates of 0,60 , and $120 \mathrm{~kg} \mathrm{ha}^{-1}$

Table 2 - Silage yield and plant morphology as a function of nitrogen fertilization rates, inoculation with Azospirillum brasilense, and maize hybrids (2012/2013 and 2013/2014 harvests)

\begin{tabular}{|c|c|c|c|c|c|c|c|c|}
\hline & $\begin{array}{c}\text { GPW } \\
\left(\text { g plant }^{-1}\right)\end{array}$ & $\begin{array}{c}\text { Yield } \\
\left.(\mathrm{kg} \mathrm{DM} \mathrm{ha})^{-1}\right)\end{array}$ & $\begin{array}{c}\text { Ear } \\
---\end{array}$ & Husk & Leaf & $\begin{array}{l}\text { Senescent } \\
g^{-1}--------\end{array}$ & Stem & Tassel \\
\hline \multicolumn{9}{|l|}{$\mathrm{N}$ rate $\left(\mathrm{kg} \mathrm{ha}^{-1}\right)$} \\
\hline 60 & 733.59 & 14,251 & 397.9 & 98.2 & 160.7 & 13.5 & 327.6 & 11.8 \\
\hline 120 & 785.68 & 14,616 & 400.1 & 91.1 & 160.8 & 5.7 & 330.4 & 9.5 \\
\hline 240 & 824.98 & 15,044 & 384.4 & 93.0 & 165.2 & 3.8 & 345.6 & 11.6 \\
\hline 480 & 850.24 & 15,758 & 370.9 & 95.5 & 165.5 & 3.7 & 354.2 & 10.9 \\
\hline A. brasilense & 766.30 & 14,414 & 395.8 & 89.4 & 154.8 & 8.3 & 338.2 & 10.1 \\
\hline Control & 763.98 & 14,306 & 386.2 & 97.2 & 167.0 & 8.5 & 338.4 & 11.7 \\
\hline \multicolumn{9}{|l|}{ Hybrid } \\
\hline AS 1572 & 769.99 & 14,400 & 375.7 & 91.6 & 160.0 & 10.1 & 354.6 & 10.5 \\
\hline Defender & 760.29 & 14,320 & 406.3 & 94.9 & 161.8 & 6.6 & 322.0 & 11.3 \\
\hline \multicolumn{9}{|l|}{ F test (P-value) } \\
\hline I & 0.1919 & 0.1350 & 0.5498 & 0.0789 & 0.0932 & 0.9178 & 0.9945 & 0.0318 \\
\hline $\mathrm{H}$ & 0.5677 & 0.8165 & 0.0500 & 0.4442 & 0.6442 & 0.0952 & 0.0193 & 0.2777 \\
\hline $\mathrm{N} \times \mathrm{I}$ & 0.0453 & 0.0332 & 0.7915 & 0.0803 & 0.6476 & 0.6025 & 0.8038 & 0.3475 \\
\hline $\mathrm{N} \times \mathrm{H}$ & 0.9876 & 0.9770 & 0.4663 & 0.8154 & 0.8129 & 0.5807 & 0.4680 & 0.3278 \\
\hline $\mathrm{I} \times \mathrm{H}$ & 0.0344 & 0.0367 & 0.0484 & 0.7451 & 0.0187 & 0.7881 & 0.5103 & 0.0423 \\
\hline $\mathrm{N} \times \mathrm{I} \times \mathrm{H}$ & 0.4237 & 0.3278 & 0.1864 & 0.1961 & 0.5605 & 0.7310 & 0.6131 & 0.1270 \\
\hline
\end{tabular}

GPW - green plant weight; DM - dry matter; CV - coefficient of variation; N - nitrogen rate effect; I - inoculation effect; H - hybrid effect; N $\times$ I - nitrogen rate $\times$ inoculation interaction; $\mathrm{N} \times \mathrm{H}$ - nitrogen rate $\times$ hybrid interaction; $\mathrm{I} \times \mathrm{H}$ - inoculation $\times$ hybrid interaction; $\mathrm{N} \times \mathrm{I} \times \mathrm{H}$ - nitrogen rate $\times$ inoculation $\times$ hybrid interaction. 
favored the development of inoculated plants in relation to the control group (Figure 2). The statistical equations revealed that $\mathrm{N}$ rates between 0 and $184 \mathrm{~kg} \mathrm{ha}^{-1}$ in $A$. brasilense-inoculated plants raised the plant yield for silage when compared with the control. The $184 \mathrm{~kg} \mathrm{ha}^{-1} \mathrm{~N}$ dose denotes the intersection moment of Azosporillum and control curves (Figure 2).

According to the model, greater inoculation benefits occur when nitrogen is not added into the system, i.e., $\mathrm{N}$ dose is equal to zero (Figure 2). In this condition, A. brasilense inoculation yielded $644 \mathrm{~kg} \mathrm{DM} \mathrm{ha}^{-1}$ more in comparison with control plants, which represents superiority of $48.78 \mathrm{~g} \mathrm{~kg}^{-1}$ of DM. The silage yield increased as the $\mathrm{N}$ doses were added, but the differences between $A$. brasilense-inoculated plants and control plants declined up to $184 \mathrm{~kg} \mathrm{ha}^{-1} \mathrm{~N}$.

In the quality of maize silage, an evaluation of the means of the fermentative parameters indicated that the quality of the prepared silage was satisfactory and was not significantly different for the factors and their interactions (Table 4). The hybrid AS 1572 presented better cellular wall and nutritional composition when compared with Defender (Table 4). Nitrogen rates increased crude protein $(\mathrm{y}=76.4+0.0356 \mathrm{x})$ and decreased total

Table 3 - Interaction between inoculation with Azospirillum brasilense and maize hybrid on silage yield and plant morphological composition (2012/2013 and 2013/2014 harvests)

\begin{tabular}{lcccccc}
\hline \multirow{2}{*}{ Variable } & \multicolumn{2}{c}{ Defender } & & \multicolumn{2}{c}{ AS 1572} \\
\cline { 2 - 3 } \cline { 5 - 6 } \cline { 5 - 6 } & A. brasilense & Control & & A. brasilense & Control \\
\hline Green plant weight $(\mathrm{g})$ & $785.00 \mathrm{a}$ & $747.60 \mathrm{~b}$ & & $754.98 \mathrm{~b}$ & $773.00 \mathrm{a}$ \\
Yield (kg DM ha $\left.{ }^{-1}\right)$ & $14,593 \mathrm{a}$ & $14,019 \mathrm{~b}$ & & $14,208 \mathrm{~b}$ & $14,620 \mathrm{a}$ \\
Ear $(\%)$ & $42.39 \mathrm{a}$ & $38.87 \mathrm{~b}$ & & 36.76 & 38.38 \\
Leaf $(\%)$ & $15.09 \mathrm{~b}$ & $17.28 \mathrm{a}$ & & 15.87 & 16.12 \\
Tassel (\%) & 1.12 & 1.13 & & $0.91 \mathrm{~b}$ & $1.19 \mathrm{a}$ \\
\hline
\end{tabular}

DM - dry matter.

Means of hybrids followed by different letters in the row differ among themselves according to the $\mathrm{F}$ test $(\mathrm{P}<0.05)$. carbohydrate contents $(\mathrm{y}=846.0-0.0322 \mathrm{x})$. Inoculation with Azospirillum brasilense increased the EE content and the TDN and reduced the amount of ADF in the silage (Table 4). An interaction between inoculation and maize hybrid was indicated for cellulose, NFC, and NDIN (Table 5). Inoculation reduced the cellulose levels in the Defender hybrid, which consequently raised the amount of NFC in the inoculated hybrid.

\section{Discussion}

The response variation and interactions that were observed between agricultural years and inoculated hybrids with $A$. brasilense in this study are possible, as reported in the literature. The survival and growth of this group of bacteria under uncontrolled soil and climate conditions is very complex. The inoculation increased the DM yield of the plants by $4.35 \%$ in the $2013 / 2014$, but the same effect was not observed in the 2012/2013 agricultural year.

Because the experiments were conducted in the field in different agricultural years, it was impossible to control and recreate the weather conditions. Thus, an interaction between inoculation with $A$. brasililense and agricultural year was evident and contributed to the variability between one harvest and the other. Results were as expected, due to the enormous complexity of the survival and growth of $A$. brasilense under field conditions, which results in a complex web of interactions. Therefore, the difficulty lies in determining the specific standards for field conditions, especially in experiments conducted during different agricultural years; therefore, it is impossible to replicate the environmental conditions.

Therefore, we decided to include the agricultural year factor as a random variable in the statistical model to provide better analysis of the results. Our results indicate
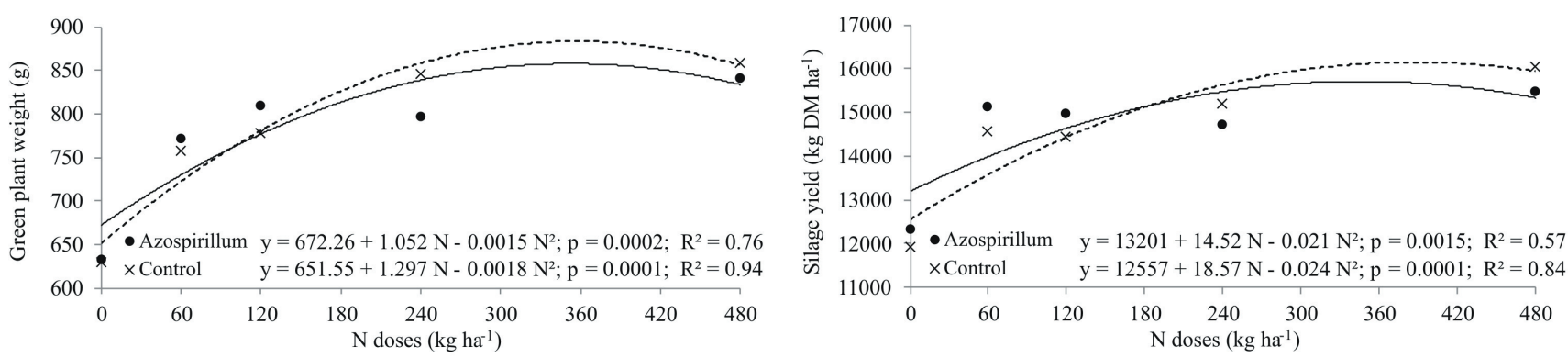

DM - dry matter; $\mathrm{R}^{2}$ - coefficient of determination.

Figure 2 - Green plant weight $(\mathrm{g})$ and silage yield $\left(\mathrm{kg} \mathrm{DM} \mathrm{ha}^{-1}\right)$ of maize hybrids subjected to increasing nitrogen rates. 
Table 4 - Fermentation characteristics and nutritional value of maize hybrids silage inoculated or uninoculated with Azospirillum brasilense and subjected to nitrogen rates (2012/2013 and 2013/2014 harvests)

\begin{tabular}{|c|c|c|c|c|c|c|c|c|c|c|c|}
\hline & \multicolumn{2}{|c|}{ Inoculation } & \multicolumn{2}{|c|}{ Hybrid } & \multicolumn{5}{|c|}{$\mathrm{N}$ rate $\left(\mathrm{kg} \mathrm{ha}^{-1}\right)$} & \multirow{2}{*}{ CV (\%) } & \multirow{2}{*}{$\mathrm{P} \leq 0.05$} \\
\hline & A. brasilense & Control & AS 1572 & Defender & 0 & 60 & 120 & 240 & 480 & & \\
\hline $\mathrm{pH}$ & 3.91 & 3.90 & 3.92 & 3.90 & 3.90 & 3.92 & 3.91 & 3.92 & 3.89 & 2.45 & NS \\
\hline $\mathrm{CP}$ & 82.8 & 82.7 & 83.4 & 82.2 & 75.1 & 77.6 & 81.9 & 87.0 & 92.2 & 9.15 & $\mathrm{~N}$ \\
\hline $\mathrm{EE}$ & $30.2 \mathrm{a}$ & $28.9 b$ & $28.7 b$ & $30.4 \mathrm{a}$ & 28.9 & 29.4 & 30.7 & 29.6 & 29.1 & 10.88 & $\mathrm{I} ; \mathrm{H}$ \\
\hline NDFap & 462.1 & 465.7 & $457.0 \mathrm{~b}$ & $470.8 \mathrm{a}$ & 466.3 & 461.9 & 455.3 & 468.0 & 468.1 & 4.00 & $\mathrm{H}$ \\
\hline CEL & 219.3 & 226.3 & 216.1 & 229.5 & 223.3 & 219.7 & 219.9 & 224.4 & 227.0 & 4.93 & $\mathrm{I} \times \mathrm{H}$ \\
\hline LIG & 32.4 & 33.1 & $31.3 \mathrm{~b}$ & $34.1 \mathrm{a}$ & 30.9 & 31.0 & 33.2 & 34.5 & 34.1 & 11.92 & $\mathrm{H}$ \\
\hline NFC & 377.6 & 374.8 & $384.6 \mathrm{~b}$ & $367.8 \mathrm{a}$ & 380.2 & 383.2 & 386.1 & 367.8 & 367.5 & 5.66 & $\mathrm{I} \times \mathrm{H}$ \\
\hline $\mathrm{TC}$ & 839.7 & 840.5 & 841.5 & 838.7 & 846.6 & 845.1 & 841.4 & 835.9 & 831.7 & 1.11 & $\mathrm{~N}$ \\
\hline ADIN & 89.8 & 92.2 & $85.2 \mathrm{~b}$ & $96.9 \mathrm{a}$ & 91.7 & 91.6 & 90.8 & 94.8 & 85.9 & 15.72 & $\mathrm{H}$ \\
\hline NDIN & 229.4 & 228.6 & 231.3 & 226.7 & 230.3 & 230.2 & 226.1 & 233.5 & 224.8 & 9.44 & $\mathrm{I} \times \mathrm{H}$ \\
\hline
\end{tabular}

$\mathrm{NH}_{3}$ - ammonium nitrogen ( $\mathrm{g} \mathrm{kg}^{-1}$ of total nitrogen); DM - dry matter $\left(\mathrm{g} \mathrm{kg}^{-1}\right)$; CP - crude protein $\left(\mathrm{g} \mathrm{kg}^{-1}\right.$ of DM); EE - ether extract ( $\mathrm{g} \mathrm{kg}{ }^{-1}$ of DM); NDFap - neutral detergent fiber corrected for ash and protein ( $\mathrm{g} \mathrm{kg}^{-1}$ of DM); ADF - acid detergent fiber $\left(\mathrm{g} \mathrm{kg}^{-1}\right.$ of DM); HEM - hemicellulose ( $\mathrm{g} \mathrm{kg}{ }^{-1}$ of DM); CEL - cellulose ( $\mathrm{g} \mathrm{kg}{ }^{-1}$ of $\mathrm{DM})$; LIG - lignin ( $\mathrm{g} \mathrm{kg}^{-1}$ of DM); NFC - non-fiber carbohydrates $\left(\mathrm{g} \mathrm{kg}^{-1}\right.$ of DM); TC - total carbohydrates ( $\mathrm{g} \mathrm{kg}^{-1}$ of DM); ADIN - acid detergent insoluble nitrogen ( $\mathrm{g} \mathrm{kg}^{-1}$ of total nitrogen); NDIN - neutral detergent insoluble nitrogen ( $\mathrm{g} \mathrm{kg}^{-1}$ of total nitrogen); TDN - total digestible nutrients ( $\mathrm{g} \mathrm{kg}{ }^{-1}$ of DM); NS - non-significant; CV - coefficient of variation;

$\mathrm{N}$ - nitrogen rate effect; I - inoculation effect; $\mathrm{H}$ - hybrid effect; $\mathrm{I} \times \mathrm{H}$ - inoculation $\times$ hybrid interaction.

Table 5 - Interaction between inoculation with Azospirillum brasilense and hybrids for the nutritional components of maize silage plants in the 2012/2013 and 2013/2014 harvests

\begin{tabular}{lccccc}
\hline \multirow{2}{*}{ Variable $^{1}$} & \multicolumn{2}{c}{ Defender } & & \multicolumn{2}{c}{ AS 1572} \\
\cline { 2 - 3 } \cline { 5 - 6 } & A. brasilense & Control & & A. brasilense & Control \\
\hline Cellulose & $216.5 \mathrm{~b}$ & $236.1 \mathrm{a}$ & & $215.8 \mathrm{~b}$ & $206.4 \mathrm{~b}$ \\
NFC & $373.0 \mathrm{~b}$ & $362.6 \mathrm{~b}$ & & $382.2 \mathrm{a}$ & $387.0 \mathrm{a}$ \\
NDIN & $231.2 \mathrm{ab}$ & $222.3 \mathrm{~b}$ & & $227.7 \mathrm{ab}$ & $234.9 \mathrm{a}$ \\
\hline
\end{tabular}

Cellulose ( $\mathrm{g} \mathrm{kg}^{-1}$ of DM); NFC - non-fiber carbohydrates $\left(\mathrm{g} \mathrm{kg}^{-1}\right.$ of DM); NDIN neutral detergent insoluble nitrogen $\left(\mathrm{g} \mathrm{kg}^{-1}\right.$ of total nitrogen).

Means followed by different letters in the row differ according to the $F$ test $(\mathrm{P}<0.05)$.

the need for a search for Azospirillum brasilense strains able to grow and contribute to the plants under specific soil and climatic conditions to reduce the variability of inoculation responses. In this way, Ilyas and Bano (2010) verified that strains isolated from semi-arid and arid soils (between 80 and $160 \mathrm{~g} \mathrm{~kg}^{-1}$ of moisture) or plots subjected to a restricted water regimen $\left(8 \mathrm{~g} \mathrm{~kg}^{-1}\right.$ of moisture) had a higher tolerance to water stress in wheat plants than strains isolated from irrigated fields, or from plots subjected to an adequate water regime.

The activity and survival of $A$. brasilense vary with $\mathrm{pH}$, humidity, water activity, oxygen, temperature, plant conditions, and other factors (Bashan et al., 2004; Hungria et al., 2010; Joe et al., 2012; Oliveira et al., 2004). Abril et al. (2006) reported that a definite standard for root colonization by bacteria introduced through inoculants in the field seems to not exist. Thus, bacterial colonization is strongly affected by environmental conditions and competition with other strains or native microbiota, which explains the contradictory results and the variations found under field conditions. The authors determined that the degree of root colonization by Azospirillum spp. was specifically affected by water stress and the origin of the inoculant strains.

An associative effect between $A$. brasilense strains $\mathrm{Ab}-\mathrm{V} 5$ and $\mathrm{Ab}-\mathrm{V} 6$ and the hybrids seems to be determined by the specific soil and climatic conditions for the harvest in each agricultural year, which contributed to the association between the bacteria and the plant, either benefiting a specific hybrid or contributing to another hybrid. In this case, it was not possible to obtain a standard response.

It is also possible that bacterial colonization and the production response are associated with the root exudates released by the different genotypes. According to Haichar et al. (2008), Husson (2013), and Merino et al. (2015), the microorganisms are attracted to the roots by recognizing specific chemicals or attracted by the gradient of carbon sources that occurs between the soil and the rhizosphere. Blanco et al. (2015) demonstrated that the nitrogen fertilization, and especially some maize genotypes, affected the quantity and diversity of the diazotrophic bacteria associated with the plant rhizosphere. Liebersbach et al. (2004) reported that an increase in the release of root exudates occurred under water and nutritional stress conditions, which may contribute to this type of association. 
Defender hybrid inoculated with $A$. brasilense showed a higher ear and a lower leaf proportion when compared with uninoculated hybrid. According to Dobbelaere et al. (2002), increases in yield, prolificacy, ear length, and number of grains were observed in maize and wheat inoculated with $A$. brasilense. According to Lakzadeh et al. (2015), inoculation with $A$. brasilense improves environmental/biochemical conditions and soil nutrition, increasing the flowers and pollen production. This is due to the higher nitrogen availability in the soil due to BNF and to the phytohormone synthesis which provide greater water and nutrient uptake due to changes in the physiology and increment of the root system.

Interactions of $A$. brasilense and $\mathrm{N}$ rates represent relevant scientific contribution. Results indicate that plants inoculated with $A$. brasilense have higher nitrogen efficiency use up to $184 \mathrm{~kg} \mathrm{ha}^{-1} \mathrm{~N}$ when compared with control plants. These data coincide with the $\mathrm{N}$ rates applied by Brazilian maize farmers, which may benefit from $A$. brasilense inoculation through higher productivity, or even reduction of $\mathrm{N}$ doses applied. Results described by Galindo et al. (2016) are similar to our study. These authors verified that $A$. brasilense inoculation produced significant responses on the agronomic efficiency of maize in $\mathrm{N}$ rates of 50 and $100 \mathrm{~kg} \mathrm{ha}^{-1}$, since it indicates that less $\mathrm{N}$ was lost when plants had been inoculated with this diazotroph. They also observed that the agronomic efficiency linear function decreased only with $A$. brasilense at higher $\mathrm{N}$ rates, in the same way as described in our study.

The interaction observed between the $\mathrm{N}$ rates and inoculation with $A$. brasilense indicate that it is possible that high $\mathrm{N}$ rate applied as topdressing could compromise the success of inoculation with $A$. brasilense, particularly in terms of BNF. This effect may be due to the rapid and reversible reduction in nitrogenase activity, which is inhibited by the addition of $\mathrm{NH}_{4}^{+}$to the soil, due to the high energy cost of $\mathrm{N}_{2}$ reduction (Reis and Teixeira, 2005). Under such circumstances, the inoculation results might depend on a low concentration of mineral $\mathrm{N}$ in the soil or a low or medium level of applied N. Hartmann et al. (1986) verified, after the addition of very low concentrations of ammonium, that nitrogen fixation is rapidly and reversibly inhibited in Azospirillum spp. A covalent modification of the nitrogenase reductase of $A$. brasilense and A. lipoferum was demonstrated by these authors.

Zemrany et al. (2006) reported that bacterial survival in an inoculant is a prerequisite for positive effects on the plant. In an evaluation of A. lipoferum strain CRT1 in the maize rhizosphere over two years, they found that the strain successfully survived, especially during the first two months after inoculation, which indicated that the ecological conditions were suitable for an expected positive effect on plant growth. An increase in root depth and root biomass was reported. However, the aerial parts of the plants, including grain yield, remained unchanged. This failure was attributed to the high availability of $\mathrm{N}$ in the soil because agricultural practices in France call for the use of large amounts of nitrogen, which allowed the culture to improve itself by the use of $\mathrm{N}$ in crops and the years before the experiment. Thus, positive inoculation results are more likely to be obtained when the availability of $\mathrm{N}$ in the soil is limited, with the most sustainable use of $\mathrm{N}$ fertilization. On the other hand, scientific studies have shown positive responses of inoculation with $A$. brasilense in soil that contains large amounts of available N (Dobbelaere et al., 2003; Araújo et al., 2014). In this way, lager bacterial development occurs and, therefore, an increase of crop yield occurs due to the production of the phytohormones (cytokinin, gibberellin, and indole-acetic acid), increasing the $\mathrm{N}$ fertilization efficiency. The mechanism behind this is attributed to the general increase of the root system, allowing the plant to explore larger volume of soil. This results in an increase of $\mathrm{N}$ uptake and higher biomass production (Cassan et al., 2009; Hungria et al., 2010; Moutia et al., 2010).

In addition, the analyses of the silage nutritional value showed that inoculation with $A$. brasilense modified the cell wall structure and other components associated with the nutritional value and energy level (TDN) of the silages. Although moderate, changes occurred in two experimental harvests in different years, which indicates some robustness of the results and that inoculation may have some effect on the cell wall content of the plants and the quality of the ensiled materials. However, with these results, it is not possible to definitely conclude upon nutritive value of maize silage.

\section{Conclusions}

Positive results with inoculation are dependent on nitrogen fertilization rate. The interaction between Azospirillum brasilense inoculation and maize hybrids seems to be associated with specific soil and climate conditions for each agricultural year, not allowing a standard to be set for the association between the A. brasilense $\mathrm{Ab}-\mathrm{V} 5$ and Ab-V6 strains and the maize hybrids.

Inoculation with $A$. brasilense can promote changes in the maize silage quality, but it is not possible to conclude definitely on the subject. 


\section{References}

Abril, A.; Biasutti, C.; Maich, R.; Dubbini, L. and Noe, L. 2006. Inoculación con Azospirillum spp. en la Región Semiárida-Central de Argentina: factores que afectan la colonización rizosférica. Ciência del Suelo 24:11-19.

Araújo, R. M.; Araújo, A. S. F.; Nunes, L. A. P. L. and Figueiredo, M. V. B. 2014. Resposta do milho verde à inoculação com Azospirillum brasilense e níveis de nitrogênio. Ciência Rural 44:1556-1560.

AOAC - Association of Official Analytical Chemists. 1995. Official methods of analysis. 16th ed. AOAC International, Arlington.

Bashan, Y. and Bashan, L. E. 2010. How the plant growth-promoting bacterium Azospirillum promotes plant growth a critical assessment. Advances in Agronomy 108:77-136.

Bashan, Y.; Holguin, G. and Bashan, L. E. 2004. Azospirillum plant relations physiological, molecular, agricultural, and environmental advances (1997-2003). Canadian Journal of Microbiology 50:521-577.

Blanco, R. B.; Sicardi, M. and Frioni, L. 2015. Plant genotype and nitrogen fertilization effects on abundance and diversity of diazotrophic bacteria associated with maize (Zea mays L.). Biology and Fertility of Soils 51:391-402.

Castagnara, D. D.; Mesquita, E. E.; Neres, M. A.; Oliveira, P. S. R.; Zoz, T. and Zoz A. 2014. Morphogenesis and production of Tanzânia, Mombaça and Mulato grasses under nitrogen fertilization. Bioscience Journal 30:45-54.

Cassan, F.; Perrig, D.; Sgroy, V.; Masciarelli, O.; Penna, C.; and Luna, V. 2009. Azospirillum brasilense Az39 and Bradyrhizobium japonicum E109, inoculated singly or in combination, promote seed germination and early seedling growth in maize (Zea mays L.) and soybean (Glycine max L.). European Journal of Soil Biology 45:28-35.

CEMETRS - Centro Estadual de Meteorologia. 2012. Atlas climático do Rio Grande do Sul. Porto Alegre. 198p. Available at: <http:// www.cemet.rs.gov.br/lista/676/Atlas_Clim\%C3\%Altico_do_Rio_ Grande_do_Sul>.Accessed on: May 23, 2012.

Comissão de Fertilidade do Solo - RS/SC. 2004. Manual de adubação e calagem para os Estados do Rio Grande do Sul e Santa Catarina. 10.ed. SBCS - Núcleo Regional Sul, UFRGS, Porto Alegre.

Dobbelaere, S.; Croonenborghs, A.; Thys, A.; Ptacek, D.; Okon, Y. and Vanderleyden, J. 2002. Effect of inoculation with wild type Azospirillum brasilense and A. Irakense strains on development and nitrogen uptake of spring wheat and grain maize. Biology and Fertily of Soils 36:284-297.

Dobbelaere S.; Vanderleyden J. and Okon Y. 2003. Plant growthpromoting effects of diazotrophs in the rhizosphere. Critical Reviews in Plant Science 22:107-149.

EMBRAPA - Empresa Brasileira de Pesquisa Agropecuária. 2013. Sistema brasileiro de classificação de solos. 3.ed. Brasília.

Fontoura, S. M. V. and Bayer, C. 2009. Adubação nitrogenada para alto rendimento de milho em plantio direto na região centro-sul do Paraná. Revista Brasileira de Ciência do Solo 33:1721-1732.

Galindo, F. S.; Teixeira Filho, M. C. M.; Buzetti, S.; Santini, J. M. K.; Alves, C. J.; Nogueira, L. M.; Ludkiewicz, M. G. Z.; Andreotti, M. and Bellote, J. L. M. 2016. Corn yield and foliar diagnosis affected by nitrogen fertilization and inoculation with Azospirillum brasilense. Revista Brasileira de Ciência do Solo 40:1-18.

Goering, H. K. and Van Soest, P. J. 1970. Forage fiber analysis. Agricultural Research Service, USDA, Washington.

Haichar, F. Z.; Marol, C.; Berge, O.; Rangel-Castro, J. I.; Proser J. I.; Balesdent, J.; Heulin, T. and Achouak, W. 2008. Plant host habitat and root exudates shape soil bacterial community structure. Multidisciplinary Journal of Microbial Ecology 2:1221-1230.

Hartmann, A.; Fu, H. and Burris, R. H. 1986. Regulation of nitrogenase activity by ammonium chloride in Azospirillum spp. Journal of Bacteriology 165:864-870.

Hungria, M.; Campo, R.J.; Souza, E. M. and Pedrosa, F. O. 2010. Inoculation with selected strains of Azospirillum brasilense and A. Lipoferum improves yields of maize and wheat in Brazil. Plant and Soil 331:413-425.

Husson, O. 2013. Redox potential (Eh) and pH as drivers of soil/ plant/microorganism systems: a transdisciplinary overview pointing to integrative opportunities for agronomy. Plant and Soil 362:389-417.

Ilyas, N. and Bano, A. 2010. Azospirillum strains isolated from roots and rhizosphere soil of wheat (Triticum aestivum L.) grown under different soil moisture conditions. Biology and Fertility of Soils 46:393-406.

Imran, S.; Arif, M.; Khan, A.; Khan, M. A.; Shah, W. and Latif, A. 2015. Effect of nitrogen levels and plant population on yield and yield components of maize. Advances in Crop Science and Technology 3:1-7.

Joe, M. M.; Karthikeyan, B.; Chauhan, P. S.; Shagol, C.; Islam, M. R.; Deiveekasundaram, M. and Sa, T. 2012. Survival of Azospirillum brasilense flocculated cells in alginate and its inoculation effect on growth and yield of maize under water deficit conditions. European Journal of Soil Biology 50:198-206.

Lakzadeh, B.; Mir-Mahmoodi, T. and Jalilnezha, N. 2015. Effects of Azospirillum bacteria and Gibberellin hormone on morphophysiological properties, yield and yield components of corn (Zea mays L.). Biological Forum - An International Journal 7:986-993.

Licitra, G.; Hernandez, T. M. and Van Soest, P. J. 1996. Standardization of procedures for nitrogen fractionation of ruminant feeds. Animal Feed Science and Technology 57:347-358.

Liebersbach, H.; Steingrobe, B. and Claassen, N. 2004. Roots regulate ion transport in the rhizosphere to counteract reduced mobility in dry soil. Plant and Soil 10:79-88.

Machado, J. M.; Rocha, M. G.; Quadros, L. F. F.; Confortin, A. C. C.; Santos, A. B.; Sichonany, M. J. O.; Ribeiro, L. A. and Rosa, A. T. N. 2013. Morphogenesis of native grasses of Pampa Biome under nitrogen fertilization. Revista Brasileira de Zootecnia 42:22-29.

Merino, C.; Nannipieri, P. and Matus, F. 2015. Soil carbon controlled by plant, microorganism and mineralogy interactions. Journal Soil Science and Plant Nutrition 15:321-332.

Morais, R. F.; Quesada, D. M.; Reis, V. M.; Urquiaga, S.; Alves, B. J. and Boddey, R. M. 2012. Contribution of biological nitrogen fixation to elephant grass (Pennisetum purpureum Schum.). Plant and Soil 356:23-34

Moutia, J. F. Y.; Saumtally, S.; Spaepen, S. and Vanderleydejn, J. 2010. Plant growth promotion by Azospirillum sp. In sugar cane is influenced by genotype and drought stress. Plant and Soil 337:233-242.

NRC - National Research Council. 2001. Nutrient requirements of dairy cattle. 7th ed. National Academy Press, Washington D.C.

Oliveira, A. L.; Canuto, E. L.; Silva, E. E.; Reis, V. M. and Baldani, J. I. 2004. Survival of endophytic diazotrophic bacteria in soil under different moisture levels. Brazilian Journal of Microbiology 35:295-299.

Patês, N. M. S.; Pires, A. J. V.; Silva, C. C. F.; Santos, L. C.; Carvalho, G. G. P. and Freire, M. A. L. 2007. Características morfogênicas e estruturais do capim-tanzânia submetido a doses de fósforo e nitrogênio. Revista Brasileira de Zootecnia 36:1736-1741. 
Peel, M. C.; Finlayson, B. L. and Mcmahon, T. A. 2007. Updated world map of the Köppen-Geiger climate classification. Hydrology and Earth System Sciences 36:1633-1644.

Reis, V. M. and Teixeira, K. R. S. 2005. Fixação biológica de nitrogênio - estado da arte. p.151-180. In: Processos biológicos no sistema solo-planta: ferramentas para uma agricultura sustentável. Brasília.

Sangoi, L.; Vargas, V. P.; Schimitt, A.; Pletsch, A. J.; Vieira, J.; Saldanha, A.; Siega, E.; Carniel, G.; Mengarda, R. T. and Picoli Junior, G. J. 2011. Disponibilidade de nitrogênio, sobrevivência e contribuição dos perfilhos ao rendimento de grãos do milho. Revista Brasileira de Ciência do Solo 35:183-191.

Streck, V. E.; Kämpf, N.; Dalmolin, R. S. D.; Klamt, E.; Nascimento, P. C.; Schneider, P.; Giasson, E. and Pinto, L. F. S. 2008. Solos do Rio Grande do Sul. EMATER/RS-ASCAR, Porto Alegre.

Van Soest, P. J.; Robertson, J. B. and Lewis, B. A. 1991. Methods for dietary fiber, neutral detergent fiber, and non-starch polysaccharides in relation to animal nutrition. Journal of Dairy Science 74:3583-3597.

Wilson, J. R. 1993. Organization of forage plant tissues. p.1-32. In: Forage cell wall structure and digestibility. Jung, H. G.; Buxton, D. R.; Hatfield, D. and Ralph, J., eds. Madison, Wisconsin, USA.

Wilson, R. F. and Wilkins, R. J. 1972. The ensilage of autumn-sown rye. Journal of British Grassland Society 27:35-41.

WRB - World Reference Base for Soil Resources. 2014. First update 2015. IUSS Working Group. World Soil Resources Reports No. 106. FAO, Rome.

Zemrany, H.; Cortet, J.; Lutz, M. P.; Chabert, A.; Baudoin, E.; Haurat, J. and Moënne-Loccoz, Y. 2006. Field survival of the phytostimulator Azospirillum lipoferum CRT1 and functional impact on maize crop, biodegradation of crop residues, and soil faunal indicators in a context of decreasing nitrogen fertilization. Soil Biology and Biochemistry 38:1712-1726. 